\title{
Antibacterial and fungicidal activities of ethanol extracts from Cotinus coggygria, Rhus typhina, R. trilobata, Toxicodendron orientale, Hedera helix, Aralia elata, Leptopus chinensis and Mahonia aquifolium
}

\author{
V. V. Zazharskyi*, P. O. Davydenko*, O. M. Kulishenko*, I. V. Borovik*, V. V. Brygadyrenko** \\ *Dnipro State Agrarian and Economic University, Dnipro, Ukraine \\ **Oles Honchar Dnipro National University, Dnipro, Ukraine
}

Article info

Received 20.03.2020

Received in revised form 14.04.2020

Accepted 16.04.2020

Dnipro State Agrarian and Economic University Sergiv Efremov st., 25 , Dnipro, 49000, Ukraine. Tel.: +38-056-713-51-74 E-mail:

zazharskivy@gmail.com

Oles Honchar Dnipro National University, Gagarin av., 72, Dnipro, 49010, Ukraine. Tel: + 38-050-93-90-788. E-mail:brigad@ua.fm

Introduction

Recently, reports have appeared with increasing frequency about the potential possibilities of the search for effective antibacterial substances in plant extracts in the context of the spread of antibiotic poly-resistant strains which are hard to treat (Zazharskyi et al., 2019a; Palchykov et al., 2020). Natural products produced by Embryophyta as secondary metabolites were found to be a rich source of biologically active compounds which may be the basis for the development of novel chemical substances for pharmaceutical preparations (Boyko \& Brygadyrenko, 2016; Zazharskyi et al., 2019b; Palchykov et al., 2019). Plants contain a diverse group of very valuable and available resources of secondary metabolites, such as tannins, terpenoids, alkaloids and flavonoids with important pharmacological properties (Georgiev et al., 2014; Jeruto et al., 2017; Hussein \& ElAnssary, 2019; Zazharskyi et al., 2019c). In general, herbal essential oils and extracts of many species of plants are considered as non-phytotoxic compounds and until now were surveyed only for presence of different types of biological activity, and their antimicrobial, anti-inflammatory, antioxidant, antimutagenic and anticancer effect have been partly described (Giriraju \& Yunus, 2013; Matić et al., 2013; Kchaou et al., 2014).

Cotinus coggygria Scop., also known as smoke tree, is one of two species which compose a small genus of the Anacardiaceae family. It has dova and the Caucasus to Central China and the Himalayas (Novakovic et al., 2007). This plant is usually considered a large bush or small tree. The leaves are glaucous, simple, ovoid, $3-8 \mathrm{~cm}$ long. The flowers are pentagonal, pale yellow or yellow-green, hermaphrodite, or some of them are abortive, with long pedicels, in indeterminate inflorescences.

Plants of the Anacardiaceae family are well-known for their cultivated edible fruits and seeds, dermatitis-causing taxa (for example, Comocladia, Metopium, Semecarpus, Toxicodendron), medical compounds, valuable timber and varnish-bearing plants (Toxicodendron and Gluta). Many species of Anacardiaceae are also valuable for their attractiveness in gardens. Specimens of Rhus, Schinus, Searsia, Pistacia chinensis Bunge, $P$. mexicana Kunth, Smodingium and Toxicodendron are attractive because of their beautiful inflorescences, evergreen or bright-coluored autumn leaves. Some products of the species of the Anacardiaceae family, including mango (Mangifera indica L. and other species), pistachio (Pistacia vera L.), cashew (Anacardium occidentale L.) and rose pepper (Schinus terebinthifolius L.) are used in food all around the globe.

Rhus typhina L. is a fast-growing species which reproduces by rhizomes and seeds. Due to its biological advantages, this deciduous species of the Anacardiaceae family has been brought to urbanized landscapes of Ukraine from native areas in the East of North America. Dzhygan et al. 
(2018) analyzed the changes in morphometric and physiological parameters of 12-year old plants of this species in artificial phytocenoses near the roads in Pavlohrad (Ukraine). Compared with plants in relatively clean zone, the greatest decrease in the length of annual shoots of the trees was observed in those at the distance of $25-40 \mathrm{~m}$ from the highway. Leaves of $R$. typhina contain several galloyltransferases which catalyze $\beta$-glucogallin-dependent transformation of 1,2,3,4,6-pentagalloylglucose to gallotannins, have excellent thermostability and high tolerance to cold (Niemetz \& Gross, 2001). Allelopathy plays a role in the formation of resistance of R. typhina to invasion (Wei et al., 2017). Wang \& Zhu (2017) suggest using $R$. typhina as an antioxidant in food, nutraceutical and cosmetic industries.

Methanol extract of leaves of $C$. coggygria was tested against seven strains of bacteria (B. subtilis, $S$. aureus, E. coli, E. aerogenes, K. pneumoniae, $P$. vulgaris and $P$. aeruginosa) using the method of disk diffusion. Extract from C. coggygria in the concentration of $10,20 \mu \mathrm{g} / \mathrm{mL}$ and $1 \mathrm{mg} / \mathrm{mL}$ displayed moderate effect on all the named strains of bacteria (Singh et al., 2012).

Method of diffusion in agar was used to assess the activity of hexane, ethanolic and aqueous extracts from C. coggygria in the concentrations of $12.5,25$ and $50 \mathrm{mg} / \mathrm{mL}$ towards Streptococcus mutans, S. sobrinus, Lactobacillus casei and Actinomyces viscosus. Water and ethanolic extracts of C. coggygria demonstrated significant activity against all four indicated bacteria in all of the tested concentrations (Ferrazzano et al., 2013).

Essential oils from leaves with young shoots of $C$. coggygria in Serbia were tested for antibacterial and antifungal activities (Novaković et al., 2007). Essential oil produced inhibition zones measuring 6-23 mm. The largest inhibition zones were observed against species of Staphylococcus and Micrococcus genera, while the smallest were observed against Proteus mirabilis. Essential oil exerted higher antibacterial activity than streptomycin, which was used as positive control, except in the case of P. mirabilis. Bacteriostatic activity of the oil ranged within the concentrations of $2.5-5.0 \mu \mathrm{L} / \mathrm{mL}$, while its bactericidal concentration -2.5 $10.0 \mu \mathrm{L} / \mathrm{mL}$.

There are two major ways of action of antiviral agents: the first one is inhibiting infection, and the other is inhibition of replication of virus. The activity of the extract from C. coggygria against infection and replication was determined using the methods of local effect and disk method (Jing et al., 2012). Ethanol extract from leaves of C. coggygria exhibited especially strong inhibiting activity towards the infection with Tobacco mosaic virus (TMV - 93.5\%), and significantly inhibited the replication of this virus (38.2\%).

Ilczuk \& Jacygrad (2016) assessed the efficiency of aqueous extract from C. coggygria in an in vitro experiment against the tissue factor in the samples of saliva obtained from clinically healthy people. Extract from C. coggygria caused increase in the buffer ability of the saliva, decrease in the number of bacteria and prevented the aggregation of bacteria.

Rendeková et al. (2015) determined the anti-biofilm activity of extract from C. coggygria against two strains from the collection and ten clinical strains of $S$. aureus. The tested extract exerted bactericidal activity against all strains of $S$. aureus, particularly strains sensitive to meticyllin (in the concentrations of $0.313-0.625 \mathrm{mg} / \mathrm{mL}$ ) The concentrations of extract from C. coggygria which inhibited the formation of biofilm were 10-100 times higher (up to $32 \mathrm{mg} / \mathrm{mL}$ ). Phytochemical analysis of C. coggygria detected quercetin, rhamnoside, methyl gallate and methyl trigallate as the main constituents of the extract. The results of the research revealed that C. coggygria is rich in tannins and flavonoids and is a promising local antibacterial preparation with anti-biofilm activity (Rendeková et al., 2015). C. coggygria is a commercial decorative plant with broad range of medical use. It is one of the most important species of trees used in ecological and landscape plantations in China, the main component of the landscape formed of red leaves in Beijing region in autumn (Wang et al., 2012; Fraternale \& Ricci, 2018).

Species of the Hedera genus are widely used in greening. Researchers from Dresden University of Applied Sciences (Germany) are undertaking surveys on hydroponic facing of facades using Hedera (Koleva, 2015), as well as possibility of future optimization of these new ecosystems.

Hu \& Wang (2008) demonstrated that arasolide A obtained from the seeds of Aralia elata (Miq.) Seem.) has anti-inflammatory activity which inhibits the production of $\mathrm{NO}$ and anti-cancer activity against SNU, cancer cells of AGS and cancer cells of melanoma, despite its low antioxidant activity. Hu \& Wang (2008) presume that triterpene saponins from A. elata can play important role in displaying antibacterial and neuroprotective properties of tinctures of the plant.

Fadıloğlu \& Çoban (2019) state that alcohol extract of Rhus trilobata Nutt. may be used as a natural antioxidant, antibacterial agent and glaze material for slowing of the oxidation of lipids and inhibition of loss of quality of frozen fish.

Zhang \& Shi (2020) presume that correct addition of Leptopus chinensis (Bunge) Pojark. could be one of the strategies of feeding which improve the digestion and digestion of dietary fibre and potentially reduce deficiency in quality feed for ruminant animals, modeling the microbial community of scar.

Therefore, the species of plants we analyze in this paper remain unstudied regarding their antimicrobial activity and could have a significant potential for human and veterinary medicine. The objective of this article was determining the antibacterial effect of ethanol extracts from Cotinus coggygria, Rhus typhina, R. trilobata, Toxicodendron orientale, Hedera helix, Aralia elata, Leptopus chinensis and Mahonia aquifolium on separate species of microorganisms in in vitro experiments.

\section{Materials and methods}

The leaves and shoots of eight species of plants (Table 1) were collected in the territory of the Botanical Garden of Oles Honchar Dnipro National University (Khromykh et al., 2018; Boyko \& Brygadyrenko, 2019), dried at room temperature, fragmented, weighed and maintained for 10 days in $70 \%$ ethyl alcohol, and filtered.

Antibacterial activity of the plant tinctures were determined using disk diffusion in agar. From daily culture of ethanol strains of microorganisms, we prepared weighed amounts according to the standard of opacity of bacterial suspension equaling 0.5 units of density according to McFarland (McF) $1.5 \times 10^{8} \mathrm{CFU}$ (colony-forming units), which was determined using a densitometer (Densimeter II).

The obtained weighed amount was inoculated to Muller-Hinton agar (Himedia) with subsequent cultivation in TCO-80/1 thermostat for $24 \mathrm{~h}$ at the temperature of $37^{\circ} \mathrm{C}$. On top of the inoculations, we put disks saturated with the tinctures of the extracted ethanol tinctures of four species of plants (Table 1).

Table 1

Used part of four species of plants and the most important information on their antibacterial activity

\begin{tabular}{llll}
\hline \multicolumn{1}{c}{ Family } & \multicolumn{1}{c}{ Species } & Used part of the plant & \multicolumn{1}{c}{ Literature sources about the action of plants on bacteria } \\
\hline & Cotinus coggygria Scop. & shoots & Novakovic et al. (2007) \\
Anacardiaceae & Rhus trilobata Nutt. & shoots & Pfeiffer \& Drinnenberg (2010) \\
& R. typhina L. & leaves & Kossah et al. (2011), Zhu et al. (2020) \\
& Toxicodendron orientale Greene & leaves & Zhao \& Zhu (2014), Krüger (2017) \\
Araliaceae & Hedera helix Linnaeus & leaves & Pane et al. (2007), Pollet et al. (2009), Strelau et al. (2018) \\
Phyllanthaceae & Aralia elata (Miq.) Seem. & leaves & Zhang et al. (2018) \\
Berberidaceae & Leptopus chinensis (Bunge) Pojark. & leaves & Zhang \& Shi (2020) \\
\hline
\end{tabular}

As positive control, we used disks with $15.0 \mu \mathrm{g}$ of azithromycin 9-deoxo-9a-aza-9a-methyl-9a-homoerythromycin A - macrolide antibiotic of broad spectrum of action. Discs with $15.0 \mu \mathrm{g}$ amphotericinin were

also used as a second control against C. albicans (Valle et al., 2015). After $24 \mathrm{~h}$, the growth of the culture was assessed using antibiotic zone scale for measuring the growth inhibition zones of microorganisms (Antibiotic 
Zone Scale-C, model PW297, India) and software TpsDig2 (F. James Rohlf, 2016). The data in tables are presented as $\mathrm{x} \pm \mathrm{SD}$ (standard deviation).

\section{Results}

Prevention of growth of separate strains of microorganisms was seen under the influence of ethanol extracts from the studied plants (Table 2,3).

C. coggygria exhibited the highest inhibiting activity, slowing the growth of $E$. faecalis $(10.2 \mathrm{~mm}$, hereafter the average radius of growth inhibition zone is indicated in $\mathrm{mm}$ ), two strains of $E$. coli (F50 and 055 16.4 and $12.4 \mathrm{~mm}$ respectively), Proteus vulgaris (10.7), P. mirabilis (12.4), S. marcescens (13.7) during moderate slowing of growth for
Y. enterocolitica (5.7). The extract from Rhus typhina competed with C. coggygria for influence on E. faecalis (11.3), E. coli F50 (12.5), S. aureus and S. epidermidis (8.3 and 10.7), L. ivanovi (9.7), C. xerosis (11.7), Rh. equi (10.3), P. vulgaris (9.6), S. typhimurium and S. adobraco (10.2 and 10.6), S. marcescens (12.3) and C. albicans (9.3), and at the same time moderately slowed the growth of $B$. subtilis (3.5), P. mirabilis (7.8), P. aeruginosa ATCC 2799 (6.3) and Y. enterocolitica (4.5). Antibacterial effectiveness was determined for alcohol extract of $R$. trilobata against E. faecalis (10.4), E. coli 055 (11.4), P. vulgaris and P. mirabilis (11.7 and 20.7), Y. enterocolitica (11.3), it also moderately slowed the growth of $P$. aeruginosa (4.2). Extract of T. orientale had notable inhibiting activity towards $E$. faecalis (12.7), $P$. vulgaris (10.5), moderate activity towards E. coli 055 (6.8) and P. mirabilis (8.7).

Table 2

The width of zone of growth inhibition $(\mathrm{mm})$ for the ethanol extracts of Anacardiaceae families against 24 strains of microorganisms $(\mathrm{n}=8)$

\begin{tabular}{|c|c|c|c|c|c|}
\hline Strains of microorganisms & Cotinus coggygria & Rhus typhina & Rhus trilobata & Toxicodendron orientale & Control* \\
\hline Enterococcus faecalis ATCC 19433 & $10.2 \pm 1.32$ & $11.3 \pm 1.13$ & $10.4 \pm 0.78$ & $12.7 \pm 1.34$ & $23.9 \pm 2.45$ \\
\hline Enterobacter aegorenes ATCC 10006 & $2.7 \pm 0.19$ & $1.6 \pm 0.14$ & $4.2 \pm 0.42$ & $2.6 \pm 0.41$ & $15.9 \pm 1.67$ \\
\hline Escherichia coli $\mathrm{F} 50$ & $16.4 \pm 1.56$ & $12.5 \pm 1.24$ & $0 \pm 0$ & $1.5 \pm 0.16$ & $17.8 \pm 1.87$ \\
\hline E. coli 055 & $12.4 \pm 1.34$ & $0 \pm 0$ & $11.4 \pm 1.43$ & $6.8 \pm 0.55$ & $15.6 \pm 1.62$ \\
\hline Staphylococcus aureus ATCC 25923 & $13.3 \pm 1.12$ & $8.3 \pm 0.46$ & $15.8 \pm 1.29$ & $10.8 \pm 0.87$ & $21.6 \pm 2.45$ \\
\hline S. epidermidis ATCC 14990 & $11.9 \pm 1.54$ & $10.7 \pm 1.22$ & $14.4 \pm 0.78$ & $0 \pm 0$ & $10.3 \pm 1.34$ \\
\hline Bacillus subtilis ATCC 6633 & $0 \pm 0$ & $3.5 \pm 0.86$ & $12.8 \pm 1.45$ & $4.5 \pm 0.77$ & $30.3 \pm 3.05$ \\
\hline B. cereus ATCC 10702 & $12.6 \pm 1.43$ & $2.3 \pm 0.89$ & $9.5 \pm 1.76$ & $4.2 \pm 0.92$ & $16.8 \pm 1.86$ \\
\hline Listeria ivanovi & $9.8 \pm 0.7$ & $9.7 \pm 0.87$ & $9.9 \pm 0.77$ & $4.3 \pm 0.32$ & $14.7 \pm 1.21$ \\
\hline L. іппосиа АТСС 33090 & $0 \pm 0$ & $0 \pm 0$ & $0 \pm 0$ & $10.7 \pm 1.41$ & $25.1 \pm 1.98$ \\
\hline L. monocytogenes ATCC 19112 & $0 \pm 0$ & $0 \pm 0$ & $0 \pm 0$ & $0 \pm 0$ & $0 \pm 0$ \\
\hline Corynebacterium xerosis 1911 & $15.8 \pm 1.45$ & $11.7 \pm 1.23$ & $11.5 \pm 0.78$ & $11.7 \pm 0.79$ & $9.3 \pm 1.34$ \\
\hline Campylobacter jejuni ATCC 11322 & $0 \pm 0$ & $0 \pm 0$ & $0 \pm 0$ & $12.7 \pm 1.43$ & $0 \pm 0$ \\
\hline Rhodococcus equi ATCC 6939 & $11.7 \pm 0.83$ & $10.3 \pm 0.12$ & $12.6 \pm 1.36$ & $10.2 \pm 0.89$ & $19.1 \pm 1.98$ \\
\hline Proteus vulgaris ATCC 13315 & $10.7 \pm 1.22$ & $9.6 \pm 0.86$ & $11.7 \pm 1.28$ & $10.5 \pm 1.12$ & $0 \pm 0$ \\
\hline P. mirabilis ATCC 14153 & $12.4 \pm 1.21$ & $7.8 \pm 0.88$ & $20.7 \pm 2.24$ & $8.7 \pm 0.67$ & $0 \pm 0$ \\
\hline Salmonella typhimurium ATCC 14028 & $0 \pm 0$ & $10.2 \pm 0.96$ & $0 \pm 0$ & $1.7 \pm 0.33$ & $20.3 \pm 1.54$ \\
\hline S. adobraco 1 & $0 \pm 0$ & $10.6 \pm 0.89$ & $0 \pm 0$ & $0 \pm 0$ & $26.3 \pm 2.76$ \\
\hline Pseudomonas aeruginosa ATCC 2353 & $0 \pm 0$ & $0 \pm 0$ & $10.1 \pm 0.88$ & $17.4 \pm 1.54$ & $0 \pm 0$ \\
\hline P. aeruginosa ATCC 2799 & $0 \pm 0$ & $6.3 \pm 0.41$ & $6.5 \pm 0.65$ & $6.3 \pm 0.67$ & $0 \pm 0$ \\
\hline Klebsiella pneumoniae ATCC 13883 & $0 \pm 0$ & $1.3 \pm 0.14$ & $0 \pm 0$ & $1.3 \pm 0.13$ & $0 \pm 0$ \\
\hline Yersinia enterocolitica ATCC 9610 & $5.7 \pm 0.45$ & $4.5 \pm 0.25$ & $11.3 \pm 0.94$ & $2.3 \pm 0.35$ & $12.8 \pm 1.27$ \\
\hline Serratia marcescens ATCC 8100 & $13.7 \pm 1.45$ & $12.3 \pm 1.09$ & $0 \pm 0$ & $2.8 \pm 0.25$ & $0 \pm 0$ \\
\hline Candida albicans ATCC 2091 & $11.2 \pm 1.38$ & $9.3 \pm 0.89$ & $16.8 \pm 1.78$ & $17.8 \pm 1.78$ & $0 \pm 0 * / 2.4 \pm 0.21 * *$ \\
\hline
\end{tabular}

Note: *-discs with $15.0 \mu \mathrm{g}$ of azithromycin were used for all bacteria as positive control; ** - discs with $15.0 \mu \mathrm{g}$ amphotericinin were used as positive control for $C$. albicans.

Table 3

Width of growth inhibition zone (mm) produced by ethanol extracts of Hedera helix, Aralia elata,

Leptopus chinensis and Mahonia aquifolium against 24 strains of microorganisms $(\mathrm{n}=8)$

\begin{tabular}{|c|c|c|c|c|c|}
\hline Strains of microorganisms & Hederahelix & Aralia elata & Leptopus chinensis & Mahonia aquifolium & Control* \\
\hline Enterococcus faecalis ATCC 19433 & $0 \pm 0$ & $0 \pm 0$ & $0 \pm 0$ & $3.2 \pm 0.65$ & $23.9 \pm 2.45$ \\
\hline Enterobacter aegorenes ATCC 10006 & $0 \pm 0$ & $1.3 \pm 0.17$ & $0 \pm 0$ & $1.3 \pm 0.14$ & $15.9 \pm 1.67$ \\
\hline Escherichia coli $\mathrm{F} 50$ & $3.8 \pm 0.34$ & $11.9 \pm 1.16$ & $11.5 \pm 0.78$ & $1,5 \pm 0,12$ & $17.8 \pm 1.87$ \\
\hline E. coli 055 & $0 \pm 0$ & $10.6 \pm 0.98$ & $3,6 \pm 0.32$ & $2,7 \pm 0,43$ & $15.6 \pm 1.62$ \\
\hline Staphylococcus aureus ATCC 25923 & $23.5 \pm 2.78$ & $9.7 \pm 0.78$ & $2.6 \pm 0.21$ & $2.8 \pm 0.19$ & $21.6 \pm 2.45$ \\
\hline S. epidermidis ATCC 14990 & $26.3 \pm 2.15$ & $0 \pm 0$ & $18.7 \pm 1.78$ & $21.6 \pm 2.34$ & $10.3 \pm 1.34$ \\
\hline Bacillus subtilis ATCC 6633 & $0 \pm 0$ & $0 \pm 0$ & $0 \pm 0$ & $2.2 \pm 0.67$ & $30.3 \pm 3.05$ \\
\hline B. cereus ATCC 10702 & $0 \pm 0$ & $15.8 \pm 2.34$ & $10.8 \pm 0.98$ & $4.7 \pm 1.21$ & $16.8 \pm 1.86$ \\
\hline Listeria ivanovi & $0 \pm 0$ & $0 \pm 0$ & $1.6 \pm 0.19$ & $0 \pm 0$ & $14.7 \pm 1.21$ \\
\hline L. innосиа АТCC 33090 & $0 \pm 0$ & $0 \pm 0$ & $0 \pm 0$ & $0 \pm 0$ & $25.1 \pm 1.98$ \\
\hline L. monocytogenes ATCC 19112 & $9.3 \pm 1.22$ & $0 \pm 0$ & $0 \pm 0$ & $2.1 \pm 0.34$ & $0 \pm 0$ \\
\hline Corynebacterium xerosis 1911 & $4.4 \pm 0.19$ & $8.4 \pm 0.89$ & $0 \pm 0$ & $3.6 \pm 0.21$ & $9.3 \pm 1.34$ \\
\hline Campylobacter jejuni ATCC 11322 & $12.4 \pm 1.26$ & $0 \pm 0$ & $2.4 \pm 0.32$ & $17.5 \pm 1.43$ & $0 \pm 0$ \\
\hline Rhodococcus equi ATCC 6939 & $11.8 \pm 0.77$ & $2.2 \pm 0.18$ & $1.3 \pm 0.13$ & $1.6 \pm 0.21$ & $19.1 \pm 1.98$ \\
\hline Proteus vulgaris ATCC 13315 & $10.8 \pm 1.21$ & $9.3 \pm 1.11$ & $4.2 \pm 0.77$ & $9.4 \pm 0.97$ & $0 \pm 0$ \\
\hline P. mirabilis ATCC 14153 & $1.5 \pm 0.14$ & $14.7 \pm 1.34$ & $10.6 \pm 0.68$ & $4.3 \pm 0.43$ & $0 \pm 0$ \\
\hline Salmonella typhimurium ATCC 14028 & $5.4 \pm 0.77$ & $9.7 \pm 0.76$ & $0 \pm 0$ & $1.4 \pm 0.18$ & $20.3 \pm 1.54$ \\
\hline S. adobraco 1 & $0 \pm 0$ & $4.4 \pm 0.57$ & $2.3 \pm 0.22$ & $7.2 \pm 0.76$ & $26.3 \pm 2.76$ \\
\hline Pseudomonas aeruginosa ATCC 2353 & $2.8 \pm 0.54$ & $0 \pm 0$ & $0 \pm 0$ & $0 \pm 0$ & $0 \pm 0$ \\
\hline P. aeruginosa ATCC 2799 & $2.3 \pm 0.45$ & $0 \pm 0$ & $0 \pm 0$ & $2.2 \pm 0.34$ & $0 \pm 0$ \\
\hline Klebsiella pneumoniae ATCC 13883 & $0 \pm 0$ & $0 \pm 0$ & $0 \pm 0$ & $0 \pm 0$ & $0 \pm 0$ \\
\hline Yersinia enterocolitica ATCC 9610 & $4.6 \pm 0.32$ & $0 \pm 0$ & $0 \pm 0$ & $0 \pm 0$ & $12.8 \pm 1.27$ \\
\hline Serratia marcescens ATCC 8100 & $2.8 \pm 0.35$ & $8.2 \pm 0.78$ & $3.5 \pm 0.34$ & $1.1 \pm 0.16$ & $0 \pm 0$ \\
\hline Candida albicans ATCC 2091 & $10.7 \pm 1.03$ & $13.6 \pm 1.45$ & $2.6 \pm 0.32$ & $5.7 \pm 0.45$ & $0 \pm 0 * / 2.4 \pm 0.21^{* *}$ \\
\hline
\end{tabular}

Note: see Table 2.

Antibacterial effect was determined for the extracts of R. trilobata and

T. orientale on $P$. aeruginosa (10.1 and 17.4); T. orientale - against C. jejuni (12.7), both of which had antibiotic resistance to azithromycin (growth inhibition zone of $0 \mathrm{~mm}$ ). Also, significant inhibiting effect of the tested alcohol extracts should be noted against $S$. aureus (15.8 and $10.8 \mathrm{~mm}$, respectively). During the study on the influence of the extracts 
on the microorganisms of the Bacillaceae family, notable impact was observed for C. coggygria on B. cereus (12.6) and R. trilobata on B. subtilis and $B$. cereus (12.8 and 9.5). Moderate and high inhibitory effects on the microorganisms of the Listeriaaceae family: C. coggygria slowed the growth of L. ivanovi (9.8), T. orientale - L. innocua (10.7). Azitromycin was not effective against $L$. monocytogenes $(0 \mathrm{~mm})$. There was seen high inhibiting effect of the extracts from $C$. coggygria, $R$. trilobata and $T$. orientale against $C$. xerosis $(15.8,11.5,11.7), R h$. equi $(11.7,12.6,10.2)$ and $C$. albicans $(11.2,16.8$ and $17.8 \mathrm{~mm}$, respectively). At the same time, the radius of the zone of inhibition of growth produced by amphotericinum equaled only $2.4 \mathrm{~mm}$.

Against the background of effective inhibition of microorganisms E. faecalis, E. coli 055 (except Rhus typhina), S. aureus, S. epidermidis (except $T$. orientale), L. ivanovi, C. xerosis, Rh. equi, $P$. vulgaris, $P$. mirabilis and $C$. albicans by ethanol extracts of plants of the Anacardiaceae family, we should note antibiotic-resistance of $P$. vulgaris, $P$. mirabilis, $K$. pneumoniae, $S$. marcescens to azithromycin $(0 \mathrm{~mm})$.

Extracts from $H$. helix, L. chinensis and $M$. aquifolium have high inhibitory effect on $S$. epidermidis $(26.3,18.7$ and $21.6 \mathrm{~mm})$, at the same time the growth inhibition zone exceeded the control by 16.0, 8.4 and $11.3 \mathrm{~mm} ; H$. helix and $A$. elata showed impact against $S$. aureus (23.5 and $9.7 \mathrm{~mm})$, C. albicans (10.7 and $13.6 \mathrm{~mm}), H$. helix, A. elata and M. aquifolium against $P$. vulgaris (10.8, 9.3 and $9.4 \mathrm{~mm}), A$. elata and L. chinensis - E. coli F50 (11.9 and $11.5 \mathrm{~mm}), B$. cereus (15.8 and $10.8 \mathrm{~mm}), P$. mirabilis (14.7 and $10.6 \mathrm{~mm}), H$. helix and M. aquifolium C. jejuni (12.4 and $17.5 \mathrm{~mm})$.

Furthermore, high antibacterial effect of $H$. helix was displayed against L. monocytogenes (9.3), A. elata - E. coli 055 (10.6), S. typhimurium (9.7), while $M$. aquifolium moderately inhibited $S$. adobraco and C. albicans (7.2 and $5.7 \mathrm{~mm}$ ). Antibiotic resistance was determined for L. monocytogenes, C. jejuni, P. vulgaris, $P$. mirabilis, $P$. aeruginosa, $K$. pneumoniae, $S$. marcescens to the control group (azithromycin 0 ) and C. albicans to amphotericinin (2.4).

\section{Discussion}

Antimicrobial activity of ethanol extract of $C$. coggygria was surveyed by Milošević et al. (2008). Extracts from leaves of $C$. coggygria inhibited $S$. aureus and $P$. aeruginosa, producing growth inhibition zones of 13 and $10 \mathrm{~mm}$. Despite the fact that $C$. albicans and $E$. coli were included in this study, Milošević et al. (2008) did not report about inhibition of these microorganisms.

Antibacterial activity of extracts from leaves of C. coggygria growing mostly naturally in Turkey (Han et al., 2009), prepared using different solvents, was determined using disk diffusion method. The extract was found to be most efficient against $E$. faecalis (diameter of the inhibition zone of $20 \mathrm{~mm}$ ) in distilled water, and methanol extract was most effective against $S$. aureus, S. epidermidis and E. faecalis (Han et al., 2009). Antimicrobial activity expressed as minimum inhibitory concentration (MIC) of acetone extract and fractions obtained from young shoots of C. coggygria ranged 3-200 mg/mL (Marčetić et al., 2012). Acetone extract inhibited the growth of Gram-positive bacteria $S$. epidermidis $(\mathrm{MIC}=$ $25 \mathrm{mg} / \mathrm{mL}$ ) and $S$. aureus (MIC $=25 \mathrm{mg} / \mathrm{mL}$ ), whereas the ethyl acetate fraction was active against $B$. subtilis ( $\mathrm{MIC}=25 \mathrm{mg} / \mathrm{mL}$ ), K. pneumoniae $(\mathrm{MIC}=50 \mathrm{mg} / \mathrm{mL})$ and $E$. coli $(\mathrm{MIC}=50 \mathrm{mg} / \mathrm{mL})$. The greatest activity with chloroform fraction was seen towards C. albicans yeasts (MIC = $3.1 \mathrm{mg} / \mathrm{mL}$ ), more efficiently than with the control antifungal preparation - nystatin $(6.2 \mathrm{mg} / \mathrm{mL})$.

Hooshyar et al. (2014) recommend further research on the use of the main constituents of $H$. helix, especially hederasaponin (saponin K10), to study the antileishmanial activity towards L. major. Shckorbatov (2017) recommends using H. helix in the sphere of food chemistry, food technologies and nutraceutical studies (for diet-therapy and cosmetics).

García-Ramírez et al. (2016) studied in vitro anti-amoebic activity of extracts from fruits and stems of Rhus trilobata towards Entamoeba histolytica. Also, Varela-Rodríguez et al. (2019) report that flavonoids, phenolic and fatty acids, and also quercetin, methyl gallate, epigallocatechin 3-cinnamate, fisetin and margaric acid, included in the content of $R$. trilobata, can have anti-cancer properties.
Aschenbeck \& Hylwa (2017) consider that Toxicodendron orientale has local antibacterial effect.

Ethanolic tincture of Aralia elata (Brygadyrenko et al., 2019) exerted low immunosuppressive action, in the conditions of high fat diet, leading to increase in the quantity of typical Escherichia coli, decrease in Enterococcus spp. and Enterobacter spp. High concentrations of it $(0.1 \%$ ethanolic tincture of A. elata) killed bacteria of Clostridium and Klebsiella genera and various yeast fungi in the intestine. Male rats on a diet with excess of fat were observed to have no serious changes in the composition of the normal gut microbiota (Bifidobacterium spp., Lactobacillus spp., Proteus spp., Staphylococcus spp., Candida spp.), and no lactose-negative enterobacteria (Citrobacter genus) were detected.

$R$. typhina decreases the diversity of the soil bacterial community compared with other species of plants: soil was characterized by higher number of Actinobacteria and lower Proteobacteria and Acidobacteria (Zhu et al., 2020). A difference was found in the relative amount of $\mathrm{No}$ cardioides and Streptomyces, which may be useful for the growth of R. typhina. Concentration of total carbon, potassium and nitrates are the main soil factors which affect the relative number of soil bacteria. Extract from $R$. typhina exhibited strong antimicrobial activity depending on the concentration and broad spectrum towards the tested bacteria of Bacillus cereus and Helicobacter pylori with MIC equaling $0.10 \%$. Yeasts displayed lower susceptibility with MIC of $0.60-0.75 \%$. Furthermore, Zhang et al. (2018) surveyed the antioxidant activity of the extract, including the absorbing activity of radicals 2,2-diphenyl-1 picrylhydrazyl (DPPH, MIC $=0.016 \mathrm{mg} / \mathrm{mL}$ ) (Kossah et al., 2011). Extract of Mahonia aquifolium is recommended for the treatment of psoriasis in humans (Sochorova, 1998; $\mathrm{Na}, 2006)$.

\section{Conclusion}

Thus, all the 8 surveyed species of plants have no notable antibacterial effect against multi-resistant strains Enterobacter aegorenes, Listeria innocua, $P$. aeruginosa ATCC 2799, K. pneumoniae. High inhibitory effect was determined for ethanol extracts from Cotinus coggygria against 13 strains of microorganisms, Rhus typhina - against 12, Rhus trilobata 14, Toxicodendron orientale - 10, Hedera helix -7, Aralia elata -10 , Leptopus chinensis -4 and Mahonia aquifolium - 3 of 24 surveyed polyresistant strains of bacteria and fungi. We think that it is possible to recommend the extracts from $C$. coggygria, $R$. typhina, $R$. trilobata, T. orientale, H. helix, A. elata, L. chinensis and M. aquifolium or individual compounds they contain for further study of methods against polyresistant strains of the abovementioned microorganisms.

\section{References}

Aschenbeck, K. A., \& Hylwa, S. A. (2017). Poison ivy and related Toxicodendron extracts in topical products. Dermatitis, 28(1), 88.

Boyko, A. A., \& Brygadyrenko, V. V. (2016a). Influence of water infusion of medicinal plants on larvae of Strongyloides papillosus (Nematoda, Strongyloididae). Visnyk of Dnipropetrovsk University, Biology, Ecology, 24(2), 519-525.

Boyko, O. O., Zazharska, N. M., \& Brygadyrenko, V. V. (2016b). The influence of the extent of infestation by helminths upon changes in body weight of sheep in Ukraine. Visnyk of Dnipropetrovsk University, Biology, Ecology, 24(1), 3-7.

Brygadyrenko, V. V., Lieshchova, M. A., Bilan, M. V., Tishkina, N. M., \& Horchanok, A. V. (2019). Effect of alcohol tincture of Aralia elata on the organism of rats and their gut microbiota against the background of excessive fat diet. Regulatory Mechanisms in Biosystems, 10(4), 497-506.

Dzhygan, O. P., Mylnikova, O. A., \& Zaitseva, I. A. (2018). The effect of vehicle exhaust emissions on morphometric and physiological characteristics of Rhus typhina. Biosystems Diversity, 26(3), 250-254.

Fadıloğlu, E. E., \& Çoban, M. Z. (2019). The effect of glazing with sumac (Rhus coriaria, L.) extract on the quality of frozen rainbow trout (Oncorhynchus mykiss) fillets. E-Journal of New World Sciences Academy, 14(4), 129-138.

Ferrazzano, G. F., Roberto, L., Catania, M. R., Chiaviello, A., De Natale, A., Roscetto, E., Pinto, G., Pollio, A., Ingenito, A., \& Palumbo, G. (2013). Screening and scoring of antimicrobial and biological activities of italian vulnerary plants against major oral pathogenic bacteria. Evidence-Based Complementary and Alternative Medicine, 2013, 1-10. 
Fraternale, D., \& Ricci, D. (2018). Chemical composition and antifungal activity of the essential oil of Cotinus coggygria from Marche Region (Italy). Natural Product Communications, 13(9), 1934578X1801300.

García-Ramírez, H. A., González-Horta, C., Infante-Ramírez, R., Talamás-Rohana, P., \& Sánchez-Ramírez, B. (2016). In vitro amoebicidal activity of the fruits and stems extracts of Rhus trilobata on Entamoeba histolytica trophozoites. Toxicology Letters, 259, S194.

Georgiev, V., Ananga, A., \& Tsolova, V. (2014). Recent advances and uses of grape flavonoids as nutraceuticals. Nutrients, 6(1), 391-415.

Giriraju, A., \& Yunus, G. (2013). Assessment of antimicrobial potential of 10\% ginger extract against Streptococcus mutans, Candida albicans, and Enterococcus faecalis: An in vitro study. Indian Journal of Dental Research, 24(4), 397.

Han, J., He, W., Song, L., Tian, C., \& Wang, J. (2009). Control of verticillium wilt in Cotinus coggygria. Forestry Studies in China, 11(1), 39.

Hooshyar, H., Talari, S., \& Feyzi, F. (2014). Therapeutic effect of Hedera helix alcoholic extract against cutaneous leishmaniasis caused by Leishmania major in Balb/c mice. Jundishapur Journal of Microbiology, 7(4), e9432.

Hu, W., Jung, M.-J., Heo, S.-I., \& Wang, M.-H. (2008). Antioxidant and antidiabetic activities of Aralia elata Seeds. Journal of Applied Biological Chemistry, 51(3), 111-116.

Hussein, R. A., \& El-Anssary, A. A. (2019). Plants secondary metabolites: The key drivers of the pharmacological actions of medicinal plants. In: Builders, P. (Ed.). Herbal medicine. IntechOpen Limited, London.

Ilczuk, A., \& Jacygrad, E. (2016). The effect of IBA on anatomical changes and antioxidant enzyme activity during the in vitro rooting of smoke tree (Cotinus coggygria Scop.). Scientia Horticulturae, 210, 268-276.

Janeczek, M., Moy, L., Lake, E. P., \& Swan, J. (2018). Review of the efficacy and safety of topical Mahonia aquifolium for the treatment of psoriasis and atopic dermatitis. Journal of Clinical and Aesthetic Dermatology, 11(12), 42-47.

Jeruto, P., Arama, P. F., Anyango, B., \& Maroa, G. (2017). Phytochemical screening and antibacterial investigations of crude methanol extracts of Senna didymobotrya (Fresen.) H. S. Irwin \& Barneby. Journal of Applied Biosciences, 114(1), 11357.

Jing, B., Ma, Z., Feng, J., Liang, H., Li, C., \& Zhang, X. (2012). Evaluation of the antiviral activity of extracts from plants grown in the Qinling Region of China against infection by Tobacco mosaic virus (TMV). Journal of Phytopathology, 160(4), 181-186.

Kchaou, W., Abbès, F., Attia, H., \& Besbes, S. (2014). In vitro antioxidant activities of three selected dates from Tunisia (Phoenix dactylifera L.). Journal of Chemistry, 2014, 1-8.

Koleva, V., \& Simeonov, E. (2015). Solid liquid extraction of phenolic and flavonoid compounds from Cotinus coggygria and concentration by nanofiltration. Chemical and Biochemical Engineering Quarterly Journal, 28(4), 545-551.

Kossah, R., Zhang, H., \& Chen, W. (2011). Antimicrobial and antioxidant activities of Chinese sumac (Rhus typhina L.) fruit extract. Food Control, 22(1), 128-132.

Krüger, C. P. (2017). 38 Rhus toxicodendron. In: Praxisleitfaden Tierhomöopathie. Narayana Verlag GmbH, Kandern. Pp. 370-379.

Marčetić, M., Božić, D., Milenković, M., Malešević, N., Radulović, S., \& Kovačević, N. (2012). Antimicrobial, antioxidant and anti-inflammatory activity of young shoots of the smoke tree, Cotinus coggygria Scop. Phytotherapy Research, 27(11), 1658-1663.

Matić, S., Stanić, S., Bogojević, D., Vidaković, M., Grdović, N., Dinić, S., Solujić, S., Mladenović, M., Stanković, N., \& Mihailović, M. (2013). Methanol extract from the stem of Cotinus coggygria Scop., and its major bioactive phytochemical constituent myricetin modulate pyrogallol-induced DNA damage and liver injury. Mutation Research/Genetic Toxicology and Environmental Mutagenesis, 755(2), 81-89.

Milošević, T., Nićiforović, N., Mihailović, V., Solujić, S., \& Vuković, N. (2008) Chemical composition and antimicrobial activity of the essential oils of flowers, leaves and stems of Cotinus coggygria. Planta Medica, 74(9), PI23.

Niemetz, R., \& Gross, G. G. (2001). Gallotannin biosynthesis: $\beta$-glucogallin: hexagalloyl 3-O-galloyltransferase from Rhus typhina leaves. Phytochemistry, 58(5), 657-661.

Novakovic, M., Vuckovic, I., Janackovic, P., Sokovic, M., Filipovic, A., Tesevic, V., \& Milosavljevic, S. (2007). Chemical composition, antibacterial and anti- fungal activity of the essential oils of Cotinus coggygria from Serbia. Journal of the Serbian Chemical Society, 72(11), 1045-1051.

Palchykov, V. A., Zazharskyi, V. V., Brygadyrenko, V. V., Davydenko, P. O., Kulishenko, O. M., \& Borovik, I. V. (2020). Chemical composition and antibacterial effect of ethanolic extract of Buxus sempervirens on cryogenic strains of microorganisms in vitro. Chemical Data Collections, 25, 100323.

Palchykov, V. A., Zazharskyi, V. V., Brygadyrenko, V. V., Davydenko, P. O., Kulishenko, O. M., Borovik, I. V., Chumak, V., Kryvaya, A., \& Boyko, O. O. (2019). Bactericidal, protistocidal, nematodicidal properties and chemical composition of ethanol extract of Punica granatum peel. Biosystems Diversity, 27(3), 300-306.

Pane, A., Raudino, F., Adornetto, S., Russo, G. P., \& Cacciola, S. O. (2007). Blight of english ivy (Hedera helix) caused by Sclerotium rolfsii in Sicily. Plant Disease, 91(5), 635-635.

Pfeiffer, G., \& Drinnenberg, J. (2010). 43 Rhus toxicodendron (Rhus-t.). In: Homöopathische Arzneimittel-Bilder Bei Hund Und Katze. Sonntag. Pp. 127-129.

Pollet, B., Steppe, K., Dambre, P., Van Labeke, M.-C., \& Lemeur, R. (2009). Temperature integration of Hedera helix L.: Quality aspects and growth response. Scientia Horticulturae, 120(1), 89-95.

Rendeková, K., Fialová, S., Jánošová, L., Mučaji, P., \& Slobodníková, L. (2015). The activity of Cotinus coggygria Scop. leaves on Staphylococcus aureus strains in planktonic and biofilm growth forms. Molecules, 21(1), 50.

Shckorbatov, Y. G. (2017). Biological and medical effects of saponins of Hedera helix and other medicinal plants. In: Aguilar, M. V., \& Otero, C. (Ed.). Frontiers in bioactive compounds. Bentham Science Publishers. Vol. 2. Pp. 186-199.

Singh, S. K., Vishnoi, R., Dhingra, G. K., \& Kishor, K. (2012). Antibacterial activity of leaf extracts of some selected traditional medicinal plants of Uttarakhand, North East India. Journal of Applied and Natural Science, 4(1), 47-50.

Strelau, M., Clements, D. R., Benner, J., \& Prasad, R. (2018). The biology of Canadian Weeds: 157. Hedera helix L. and Hedera hibernica (G. Kirchn.) Bean. Canadian Journal of Plant Science, 98(5), 1005-1022.

Varela-Rodríguez, L., Sánchez-Ramírez, B., Rodríguez-Reyna, I. S., Ordaz-Ortiz, J. J., Chávez-Flores, D., Salas-Muñoz, E., Osorio-Trujillo, J. C., Ramos-Martínez, E., \& Talamás-Rohana, P. (2019). Biological and toxicological evaluation of Rhus trilobata Nutt. (Anacardiaceae) used traditionally in Mexico against cancer. BMC Complementary and Alternative Medicine, 19, 153.

Wang, S., \& Zhu, F. (2017). Chemical composition and biological activity of staghorn sumac (Rhus typhina). Food Chemistry, 237, 431-443.

Wang, Y., Xiao, S., Xiong, D., \& Tian, C. (2012). Genetic transformation, infection process and qPCR quantification of Verticillium dahliae on smoke-tree Cotinus coggygria. Australasian Plant Pathology, 42(1), 33-41.

Wei, W., Zhou, M., Xian, X. Y., Zheng, C. X., \& Hou, Y. P. (2017). Effects of aqueous root leachates from dominant tree species on seed germination and seedling growth of exotic plant Rhus typhina L. in Shandong Peninsula. Allelopathy Journal, 40(1), 71-80.

Zazharskyi, V. V., Davydenko, P. O., Kulishenko, O. M., Borovik, I. V., \& Brygadyrenko, V. V. (2019a). Antimicrobial activity of 50 plant extracts. Biosystems Diversity, 27(2), 163-169.

Zazharskyi, V., Davydenko, P., Kulishenko, O., Borovik, I., Brygadyrenko, V., \& Zazharska, N. (2019b). Antibacterial activity of herbal infusions against Staphylococcus aureus, Staphylococcus epidermidis and Pseudomonas aeruginosa in vitro. Magyar Állatorvosok Lapja, 141, 693-704.

Zazharskyi, V., Parchenko, M., Fotina, T., Davydenko, P., Kulishenko, O., Zazharskaya, N., \& Borovik, I. (2019c). Synthesis, structure, physicochemical properties and antibacterial activity of 1,2,4-triazoles-3-thiols and furan derivatives. Voprosy Khimii i Khimicheskoi Tekhnologii, 6, 74-82.

Zhang, Y., Wang, W., He, H., Song, X., Yao, G., \& Song, S. (2018). Triterpene saponins with neuroprotective effects from a wild vegetable Aralia elata. Journal of Functional Foods, 45, 313-320.

Zhang, Z., Wang, S., Wang, M., Shahzad, K., Zhang, X., Qi, R., \& Shi, L. (2020). Effects of Urtica cannabina to Leymus chinensis ratios on ruminal microorganisms and fiber degradation in vitro. Animals, 10(2), 335.

Zhao, M., \& Zhu, H. (2014). Development and morphology of stone cells in phloem of Toxicodendron vernicifluum. Trees, 28(5), 1553-1558.

Zhu, P., Wei, W., Bai, X., Wu, N., \& Hou, Y. (2020). Effects of invasive Rhus typhina L. on bacterial diversity and community composition in soil. Écoscience, 2020, 1-8. 